\title{
Compensation Gap of Executive Team and Innovation Efficiency
}

\author{
Beibei Wang \\ School of Management, Jinan University, Guangzhou, China \\ Email: wangbeibei1203@foxmail.com
}

How to cite this paper: Wang, B. B (2020). Compensation Gap of Executive Team and Innovation Efficiency. Modern Economy, 11, 220-229.

https://doi.org/10.4236/me.2020.112019

Received: December 31, 2019

Accepted: February 1, 2020

Published: February 4, 2020

Copyright $\odot 2020$ by author(s) and Scientific Research Publishing Inc. This work is licensed under the Creative Commons Attribution International License (CC BY 4.0).

http://creativecommons.org/licenses/by/4.0/

\begin{abstract}
Based on the research of domestic and foreign scholars, this paper combines China's unique economic environment and institutional background, based on the principal-agent theory and the tournament theory, and takes the data of 2007-2016 A-share listed companies in Shanghai and Shenzhen stock exchanges as the sample. This article studies the relationship between pay gaps and innovation efficiency within executive teams. Research shows that there is a significant negative correlation between the salary gap of executive teams and the innovation efficiency, indicating that the larger the salary gap of executive teams, the lower the efficiency of $\mathrm{R} \& \mathrm{D}$ investment. The results are consistent with the argument that larger tournament incentives allow managers to make less efficient $\mathrm{R} \& \mathrm{D}$ investments.
\end{abstract}

\section{Keywords}

The Tournament Theory, Salary Gap of Executive Teams, Efficiency of R \& D

\section{Introduction}

With the advent of a knowledge-based and innovative economy, research and development have become an important link that cannot be ignored by enterprises. Innovation has exerted a growing influence on the long-term competitive advantage of enterprises and even the survival of enterprises (Eisdorfer \& Hsu, 2011). Therefore, a large number of scholars try to understand the factors driving the innovation activities of enterprises from the theoretical and empirical perspectives. In recent years, academia has called for a more detailed empirical study on the relationship between executive compensation and corporate innovation (Ederer \& Mango, 2013). According to the principal-agent theory, due to the information asymmetry between shareholders and managers, senior executives tend to avoid risks and reduce the company's long-term innovation in- 
vestment and reduce the company's innovation performance. Therefore, scholars put forward compensation incentives and other measures to promote managers to align with shareholders' goals, so that managers can increase innovation input and increase innovation output.

Tournament theory suggests that the vertical pay gap of the executive team can effectively motivate executives to work hard. But on the other hand, the pay gap may also increase the self-motivated behavior motivation and risk-taking tendency of executives. The literature on how tournament incentives affect corporate risk-taking and innovation has found that the executive team pay gap can lead to riskier corporate policies, including stronger R \& D efforts and higher leverage (Kini \& Williams, 2012). Are higher tournament incentives prompting larger venture capital investments by senior managers at the expense of efficien$c y$ ? According to the existing literature of tournament theory, no consistent conclusion can be drawn. Whether higher intensity $\mathrm{R} \& \mathrm{D}$ investment caused by higher tournament incentives is an effective investment still needs to be explored.

Contribution of this paper is mainly manifested in the following aspects: 1) from the perspective of tournament theory, the existing literature has obtained mutually contradictory empirical results, providing mixed evidence for the economic consequences of the executive team pay gap. Therefore, this paper studies the innovation efficiency, an internal indicator that affects corporate performance, in order to provide new evidence for the championship theory and provide a new attempt for the study of executive team pay gap; 2 ) in the research on innovation based on the pay gap of senior management team, the proxy variable of innovation is mainly the investment in $\mathrm{R} \& \mathrm{D}$ or the number of patents. The research of this paper focuses on the innovation efficiency, which solves the question of whether the higher intensity of $\mathrm{R} \& \mathrm{D}$ investment caused by higher tournament incentive is an effective investment. Therefore, this paper also enriches literature on innovation influencing factors.

The remainder of the study is organised as follows. In Section 2, we describe two opposite hypotheses for this article. Section 3 presents our sample selection and empirical models. Section 4 presents the results of the main estimations. We conclude in Section 5.

\section{Research Hypotheses}

\subsection{Positive Motivation of the Salary Gap of Senior Management Teams}

Classic tournament theory (Lazear \& Rosen, 1981) argues that setting CEO compensation to a high level can encourage competition and lead to better company performance. The positive incentive effect of tournaments has also been extensively tested in the past literature. Research finds that increasing the internal pay gap can significantly improve company performance and reduce equity capital costs (Main, O’Reilly, \& Wade, 1993; Chen, Huang, \& Wei, 2013). 
Relevant scholars have also found that if managers take excessive risks (probably because of promotion rewards), the risk of poor performance will be higher and the risk of dismissal will increase. This concern about employment risks may also encourage business managers to think more carefully about their risk-taking behaviors (Kempf, Ruenzi, \& Thiele, 2009). In addition, the larger the salary gap for executives, the greater the reward for promotion to CEO. Senior managers compete with each other for promotion to CEO, and they will participate in the tournament in a fair manner through active efforts (Kale, Reis, \& Venkateswaran, 2009). Based on the above, this article proposes hypothesis 1 :

H1: With other conditions unchanged, the larger the salary gap of the executive team, the higher the innovation efficiency.

\subsection{Negative Incentive of the Salary Gap of Senior Management Teams}

On the other hand, the negative incentive effect of tournaments has also received widespread attention from scholars. Related studies have found that excessive pay gaps can cause high turnover rates and increase inequity, resulting in un-cooperation and laziness within the team (DeVaro \& Gürtler, 2015). At the same time, the study found that the internal compensation gap only played a positive incentive role in the short-term, prompting agents to work hard to improve performance, while in the subsequent operating period, it would lead to adverse phenomena such as improper earnings management. In the CEO Championship, the larger the pay gap, the stronger the desire of non-CEOs to be promoted to CEO (Connelly et al., 2014). Risk sensitivity theory believes that when people feel the need to achieve a certain goal becomes greater. It is easy to take risky behaviors. Social comparison theory also suggests that people are more likely to engage in risky behavior when compared to those who gain more than themselves. Research also found that promotion incentives in CEO tournaments will prompt executives to take greater risks to increase their chances of being promoted to CEO (Smith-Doerr, Manev, \& Rizova, 2004). Companies with greater promotion incentives show higher risk corporate policies, including stronger R \& D efforts and higher leverage.

Secondly, the compensation-performance sensitivity of China's listed company executives has an asymmetric feature. The increase in salary when performance increases are significantly higher than the decrease in salary when performance decreases, i.e. stickiness. Therefore, when the salary gap within the executive team is too large, executives may adopt a more aggressive risk strategy and take high risks to achieve high returns, while failing may not need to bear the relative losses. The larger the pay gap for executives, the greater the rewards for CEOs, and the more likely they are to ignore risk and engage in risky behavior. So high tournament incentives can also lead to excessive risk-taking and inefficient innovation.

But the key to this analysis is whether non-CEO executives have a significant impact on the company's investment and financial policies. The existing litera- 
ture often focuses on incentives for CEO compensation. Because it is believed that executives below the CEO level may not have a significant impact on the company's investment and financial policies. However, recent research on corporate executive incentive mechanisms has shown that incentives for non-CEO executives are also important (Kini \& Williams, 2012). The study found that in companies with multiple divisions, the support of the vice president of the division is critical to the success of R \& D projects (Smith-Doerr, Manev, \& Rizova, 2004). Some literature also focuses on the CFO's incentives for corporate financial policies and the impact of CTO incentives on R \& D investment of enterprises. These studies have shown that non-CEO executives can have a significant impact on company investment and financial policies, affecting innovation inputs and outputs. Based on the above analysis, this article proposes hypothesis 2 :

$\mathrm{H} 2$ : With other conditions unchanged, the larger the salary gap of the executive team, the lower the innovation efficiency.

\section{Research Design}

\subsection{Research Samples and Data Sources}

The number of patent applications that can be obtained in this article is up to 2016, so the sample period for this article is 2007-2016. Take the companies listed on the Shanghai and Shenzhen stock exchanges as the research sample. Except for the R \& D expense data in this article, the financial data and corporate governance data are from the CSMAR database.

During the sample selection process, the following screenings were performed: 1) excluding financial companies; 2) excluding companies with missing data on major variables; 3 ) excluding outlier data, e.g.: the main business income is negative and the asset-liability ratio is greater than 1. After screening through the above criteria, 11,666 sample observations were finally obtained. In order to eliminate the influence of outliers, this paper winsorize the upper and lower quantiles of all continuous variables.

\subsection{Definition of Variables}

This paper studies the relationship between executive team pay gap and innovation efficiency. Therefore, the explained variable of this paper is innovation efficiency (IE), and the explained variable is the pay gap within the senior management team (Pay gap).

1) The explained variable: Innovation Efficiency (IE). This article does not focus on unilateral innovation output or input but on the efficiency of R \& D investment. Therefore, drawing on previous research methods, the patent application volume is used as the output of innovation activities, and the patent application volume can reflect the innovation level of the enterprise in a timely and reliable manner than the granted volume. The research and development costs will be used as input for innovation activities. Drawing on the research methods, this paper defines innovation efficiency as the innovation output (represented by 
Pat) generated per million yuan of R \& D expenditure (represented by RD) (Almeida, Hsu, \& Li, 2013; Frydman \& Papanikolaous, 2017). Due to the long return on investment in research and development, the company's R \& D expenses in year $t+1$ and its patent applications in the next three years are used to measure innovation efficiency. The specific calculation formula is as follows: The innovation efficiency IE is defined as $\mathrm{Pat}_{i, t+n} / \mathrm{RD}_{i, t+1}$ (where $n=1,2$, or 3 ), and the natural logarithm is taken for normalization.

2) The explanatory variable: Salary Gap of Senior Management Team. The executive compensation referred to in this article is limited to monetary compensation and does not include equity incentives. Based on the championship mechanism, this paper only focuses on the vertical pay gap between executives, i.e. the pay gap between $\mathrm{CEO}$ and non-CEO executives. Drawing on previous research methods, the average salary of the top three executives with the highest salary is regarded as the CEO salary, and the salary gap of the top management team is expressed as the average salary of the top three executives and the difference between the average compensation of other executives is taken as the natural logarithm. The specific calculation formula is as follows: Paygap = Ln [The average salary of the top three executives (or directors) - the average salary of all executives after deducting the salary of the top three executives (or directors)].

3) The control variables: Drawing on the existing literature, this article also controls the size of the company (Size), asset-liability ratio (Lev), the largest shareholder's shareholding ratio (Top 1), net cash flow (CF), corporate growth (Growth), and total asset income Rate (Roa), dual roles (Dual), board independence (Indepen), board size (Bsize). The variable definition table is shown in Table 1.

\subsection{Empirical Model}

Because the board is likely to consider innovative performance in determining manager compensation (Frydman \& Papanikolaous, 2017). There may be an inverse causal relationship between innovation performance and executive compensation. To alleviate this endogenous problem, the linear regression model in this paper tests the leading-lag relationship between tournament incentives and innovation efficiency by using the key independent variables (i.e. tournament incentives) that are at least 1 year behind the dependent variable.

$$
\begin{aligned}
\mathrm{IE}= & \beta_{0}+\beta_{1} \operatorname{Ln}(\text { Pay Gap })_{i, t}+\beta_{2} \operatorname{Size}_{i, t}+\beta_{3} \text { Growth }_{i, t}+\beta_{4} \operatorname{Lev}_{i, t} \\
& +\beta_{5} \mathrm{CF}_{i, t}+\beta_{6} \text { Roa }_{i, t}+\beta_{7} \text { Bsize }_{i, t}+\beta_{8} \operatorname{Inden}_{i, t} \\
& +\beta_{9} \mathrm{TOP}_{i, t}+\beta_{10} \operatorname{Dual}_{i, t}+\sum \text { Ind }+\sum \text { Year }_{i, t}
\end{aligned}
$$

\section{Empirical Analysis}

\subsection{Descriptive Analysis}

According to the data of China's listed company samples, this paper conducts 
Table 1. Variable definition.

\begin{tabular}{|c|c|}
\hline Variable name & Explanation \\
\hline IE1 & Innovation efficiency in the first year \\
\hline IE2 & Innovation efficiency in the next two years \\
\hline IE3 & Innovation efficiency in the next three years \\
\hline Pay gap & Executive team pay gap \\
\hline Size & Natural logarithm of total assets at the end of the year \\
\hline Bsize & Natural logarithm of total board \\
\hline Indepen & Ratio of the number of independent directors to the total number of directors \\
\hline Leverage & Ratio of total liabilities to total assets at the end of the year \\
\hline Top1 & $\begin{array}{l}\text { The ratio of the number of shares held } \\
\text { by the largest shareholder to the total number of shares }\end{array}$ \\
\hline Roa & Ratio of net profit to total assets at the end of the year \\
\hline $\mathrm{CF}$ & $\begin{array}{l}\text { Ratio of net cash flow from operating activities to } \\
\text { total assets at the beginning of the year }\end{array}$ \\
\hline Growth & Company growth \\
\hline SOE & $\begin{array}{l}\text { Dummy variable, if the company's ultimate } \\
\text { controller is state-owned, take } 1 \text {; otherwise, take } 0\end{array}$ \\
\hline Dual & $\begin{array}{l}\text { Dummy variable, if the chairman and the general manager } \\
\text { are the same person take } 1 \text {; otherwise take } 0\end{array}$ \\
\hline Year & Virtual variable \\
\hline Industry & Virtual variable \\
\hline
\end{tabular}

preliminary descriptive statistics on the main variable indicators. The results are shown in Table 2.

As can be seen from Table 2, the average salary gap in the executive team is 12.64 , the standard deviation is 0.735 , and the minimum salary gap of the executive team is 10.77 , and the maximum is 14.63 . Indicating that the average CEO pay is about 300,000 Yuan higher than non-CEO. The salary gap of the senior management team is quite large. The average value of innovation efficiency in the coming year is -0.910 , i.e. the average number of patent applications per million yuan is 0.4025 , and the standard deviation is 1.319 , indicating that the level of innovation efficiency among enterprises varies greatly. The average values of innovation efficiency in the next two and three years are -0.724 and -0.578 respectively, i.e. the average number of patent applications per million yuan is 0.4848 and 0.5610 respectively, further indicating the characteristics of long return cycles of $\mathrm{R} \& \mathrm{D}$ and innovation activities. The average value of duality is 0.286 , indicating that $28.6 \%$ of the companies in the sample are duality of $\mathrm{COB}$ and $\mathrm{CEO}$. The average value of property rights is 0.360 , indicating that $36 \%$ of the samples are state-owned enterprises.

The correlation coefficient matrix and the significance level between the main variables are shown in Table 3. As can be seen from Table 3, there is a significant correlation between most variables. Except that the correlation coefficient 
Table 2. Descriptive statistics of main variables.

\begin{tabular}{ccccccc}
\hline Variables & $\mathrm{N}$ & Min & Max & Mean & P50 & sd \\
\hline IE1 & 11,666 & -4.326 & 2.385 & -0.910 & -0.854 & 1.319 \\
IE2 & 8947 & -4.172 & 2.551 & -0.724 & -0.657 & 1.319 \\
IE3 & 7146 & -4.073 & 2.767 & -0.578 & -0.530 & 1.350 \\
Pay gap & 11,666 & 10.77 & 14.63 & 12.64 & 12.54 & 0.735 \\
Size & 11,666 & 19.88 & 25.86 & 21.91 & 21.71 & 1.213 \\
Growth & 11,666 & -0.440 & 2.208 & 0.173 & 0.113 & 0.369 \\
Leverage & 11,666 & 0.0436 & 0.867 & 0.398 & 0.384 & 0.207 \\
CF & 11,666 & -0.188 & 0.328 & 0.0513 & 0.0480 & 0.0831 \\
Roa & 11,666 & -0.126 & 0.189 & 0.0438 & 0.0410 & 0.0487 \\
Bsize & 11,666 & 1.609 & 2.708 & 2.147 & 2.197 & 0.194 \\
Inden & 11,666 & 0.333 & 0.571 & 0.372 & 0.333 & 0.0532 \\
Top & 11,666 & 8.790 & 73.67 & 35.21 & 33.58 & 14.61 \\
Dual & 11,666 & 0 & 1 & 0.286 & 0 & 0.452 \\
SOE & 11,666 & 0 & 1 & 0.360 & 0 & 0.480 \\
\hline
\end{tabular}

Table 3. Variable correlation coefficient matrix.

\begin{tabular}{|c|c|c|c|c|c|}
\hline Variable & IE1 & IE2 & IE3 & Pay gap & Size \\
\hline IE1 & 1 & & & & \\
\hline IE2 & $0.749^{* * *}$ & 1 & & & \\
\hline IE3 & $0.695^{\star * *}$ & $0.768^{\star * *}$ & 1 & & \\
\hline Pay gap & $-0.140^{\star * *}$ & $-0.151^{\star * *}$ & $-0.154^{\star * *}$ & 1 & \\
\hline Size & $-0.160^{\star \star *}$ & $-0.181^{\star * *}$ & $-0.195^{\star \star *}$ & $0.353^{\star * *}$ & 1 \\
\hline Growth & $-0.026^{\star *}$ & -0.005 & -0.007 & $0.041^{\star * *}$ & -0.003 \\
\hline Leverage & -0.014 & $-0.030^{* *}$ & $-0.035^{\star *}$ & $0.041^{\star * *}$ & $0.060^{* * *}$ \\
\hline $\mathrm{CF}$ & $-0.075^{\star \star \star}$ & $-0.056^{* * *}$ & $-0.054^{\star \star \star}$ & $0.186^{\star * *}$ & $0.057^{\star * *}$ \\
\hline Roa & $-0.055^{\star \star \star}$ & $-0.045^{\star * *}$ & $-0.057^{\star \star \star *}$ & $0.250^{\star * *}$ & $-0.081^{\star * *}$ \\
\hline Bsize & $-0.087^{\star * *}$ & $-0.104^{\star * *}$ & $-0.115^{\star \star *}$ & $0.150^{\star * *}$ & $0.293^{\star * *}$ \\
\hline Inden & $0.023^{\star *}$ & $0.043^{\star * *}$ & $0.050^{\star * *}$ & -0.0150 & $0.026^{* *}$ \\
\hline Top1 & -0.0160 & $-0.029^{\star *}$ & $-0.036^{\star * *}$ & $0.037^{\star * *}$ & $0.227^{\star * *}$ \\
\hline Dual & $0.040^{* * *}$ & $0.042^{\star * *}$ & $0.033^{\star *}$ & $0.044^{\star * *}$ & $-0.207^{\star \star *}$ \\
\hline Variable & Growth & Leverage & $\mathrm{CF}$ & Roa & Bsize \\
\hline Growth & 1 & & & & \\
\hline Leverage & -0.003 & 1 & & & \\
\hline $\mathrm{CF}$ & $0.115^{\star * *}$ & $-0.135^{\star * *}$ & 1 & & \\
\hline Roa & $0.254^{\star * *}$ & $-0.429^{* * *}$ & $0.435^{\star * *}$ & 1 & \\
\hline Bsize & $-0.027^{\star *}$ & $0.189^{\star * *}$ & $0.033^{\star * *}$ & -0.001 & 1 \\
\hline Inden & -0.010 & -0.007 & $-0.019^{\star}$ & $-0.034^{\star * *}$ & $-0.476^{\star * *}$ \\
\hline Top1 & 0.003 & $0.072^{\star * *}$ & $0.061^{\star * *}$ & $0.061^{* * *}$ & 0.006 \\
\hline Dual & $0.043^{* * *}$ & $-0.185^{\star * *}$ & -0.002 & $0.073^{* * *}$ & $-0.171^{\star * *}$ \\
\hline Variable & Inden & Top1 & Dual & & \\
\hline Inden & 1 & & & & \\
\hline Top1 & $0.070^{* * *}$ & 1 & & & \\
\hline Dual & $0.094^{\star * *}$ & $-0.030^{* * *}$ & 1 & & \\
\hline
\end{tabular}

Note. ${ }^{* *} p<0.01,{ }^{* *} p<0.05,{ }^{*} p<0.1$. 
between innovation efficiency is high, the correlation coefficients between other variables are all less than 0.5 . It can be preliminarily considered that there is no serious multicollinearity problem in the model. The correlation coefficients between the salary gap of the senior management team and the innovation efficiency of the company are $-0.14,-0.151$, and -0.154 respectively $(\mathrm{P}<0.01)$, showing a significant negative correlation, which preliminarily verified the hypothesis 2 .

\subsection{Regression Analysis}

See Table 4 for the regression results of model. All of the following regressions were cluster analyzed and Robust adjusted for standard error. As shown in Table 3 , after controlling for other variables, the regression coefficients of executive compensation in columns $1-3$ are all negative and all are significant at the level of $1 \%$, indicating that the compensation gap between executive teams and innovation efficiency are significantly negatively correlated. The relationship indicates that the larger the salary gap of the executive team lead to the lower the efficiency of R \& D investment, which supports the $\mathrm{H} 2$.

According to the results in the first column, for every $1 \%$ increase in Pay gap, the innovation efficiency decreases by about $0.111 \%$ on average. These results are consistent with the argument that larger tournament incentives allow managers to make less efficient $\mathrm{R} \& \mathrm{D}$ investments.

Table 4. Model regression results.

\begin{tabular}{|c|c|c|c|}
\hline Variable & IE1 & IE2 & IE3 \\
\hline Pay gap & $-0.111^{\star * \star}(0.0408)$ & $-0.118^{\star * *}(0.0412)$ & $-0.114^{\star \star \star}(0.0396)$ \\
\hline Size & $-0.173^{\star \star \star}(0.0354)$ & $-0.189^{* * *}(0.0354)$ & $-0.214^{\star \star \star}(0.0363)$ \\
\hline Growth & $-0.103(0.0713)$ & $-0.00913(0.0631)$ & $0.0412(0.0672)$ \\
\hline Leverage & $0.561^{\star * *}(0.197)$ & $0.518^{\star * *}(0.173)$ & $0.492^{\star * *}(0.169)$ \\
\hline $\mathrm{CF}$ & $-0.552(0.331)$ & $-0.415(0.355)$ & $-0.256(0.357)$ \\
\hline Roa & $-0.0617(0.705)$ & $0.0782(0.573)$ & $-0.526(0.758)$ \\
\hline Top & $0.00131(0.00243)$ & $0.000398(0.00244)$ & $0.000307(0.00228)$ \\
\hline Bsize & $-0.325^{\star}(0.175)$ & $-0.293(0.177)$ & $-0.306(0.205)$ \\
\hline Inden & $0.0596(0.547)$ & $0.714(0.582)$ & $1.002(0.624)$ \\
\hline Dual & $0.0408(0.0500)$ & $0.0341(0.0519)$ & $-0.0128(0.0532)$ \\
\hline Constant & $4.817^{\star \star \star}(0.723)$ & $5.365^{\star \star *}(0.710)$ & $5.923^{\star * *}(0.781)$ \\
\hline Observations & 8505 & 6421 & 4853 \\
\hline R-squared & 0.047 & 0.058 & 0.065 \\
\hline $\mathrm{F}$ & 10.87 & 23.13 & 23.43 \\
\hline Industry FE & YES & YES & YES \\
\hline Year FE & YES & YES & YES \\
\hline
\end{tabular}

Note. ${ }^{* *} p<0.01,{ }^{* *} p<0.05,{ }^{*} p<0.1$. 


\section{Conclusions}

This paper uses the data of A-share listed companies in Shanghai and Shenzhen stock exchanges from 2007-2016 as samples. Through the regression analysis, it is found that for every $1 \%$ increase in the Pay gap, the innovation efficiency decreases by about $0.111 \%$ on average. It shows that there is a significant negative correlation between the salary gap of senior management teams and the innovation efficiency, which indicates that the larger the salary gap of senior management teams, the lower the efficiency of $\mathrm{R} \& \mathrm{D}$ investment. The conclusion supports that larger tournament incentives enable managers to make less efficient $\mathrm{R}$ $\&$ D investments.

This paper mainly considers the economic consequences of the cash compensation gap of the senior management team, and does not give much consideration to the influence of the shareholding difference of the senior management team on innovation. In the future, the influence of cash compensation and shareholding amount on innovation efficiency can be comprehensively considered.

\section{Conflicts of Interest}

The author declares no conflicts of interest regarding the publication of this paper.

\section{References}

Almeida, H., Hsu, P. H., \& Li, D. (2013). When Less Is More: Financial Constraints and Innovative Efficiency. Unpublished Working Paper, San Diego: University of California. https://ssrn.com/abstract=1831786

Chen, Z., Huang, Y., \& Wei, K. J. (2013). Executive Pay Disparity and the Cost of Equity Capital. Journal of Financial and Quantitative Analysis, 48, 849-885. https://doi.org/10.1017/s0022109013000306

Connelly, B. L., Tihanyi, L., Crook, T. R. et al. (2014). Tournament Theory: Thirty Years of Contests and Competitions. Journal of Management, 40, 16-47. https://doi.org/10.1177/0149206313498902

DeVaro, J., \& Gürtler, O. (2015). Strategic Shirking in Promotion Tournaments. The Journal of Law, Economics, and Organization, 32, 620-651. https://doi.org/10.1093/jleo/ewv019

Ederer, F., \& Manso, G. (2013). Is Pay-for-Performance Detrimental to Innovation? Management Science, 59, 1496-1513. https://doi.org/10.1287/mnsc.1120.1683

Eisdorfer, A., \& Hsu, P. H. (2011). Innovate to Survive: The Effect of Technology Competition on Corporate Bankruptcy. Financial Management, 40, 1087-1117. https://doi.org/10.1111/j.1755-053x.2011.01172.x

Frydman, C., \& Papanikolaous, D. (2017) In Search of Ideas: Technological Innovation and Executive Pay Inequality. Journal of Financial Economics, 130, 1-24. https://doi.org/10.1016/j.jfineco.2018.06.014

Kale, J. R., Reis, E., \& Venkateswaran, A. (2009). Rank-Order Tournaments and Incentive Alignment: The Effect on Firm Performance. The Journal of Finance, 64, 1479-1512. https://doi.org/10.1111/j.1540-6261.2009.01470.x 
Kempf, A., Ruenzi, S., \& Thiele, T. (2009). Employment Risk, Compensation Incentives, and Managerial Risk Taking: Evidence from the Mutual Fund Industry. Journal of Financial Economics, 92, 92-108. https://doi.org/10.1016/j.jfineco.2008.05.001

Kini, O., \& Williams, R. (2012). Tournament Incentives, Firm Risk, and Corporate Policies. Journal of Financial Economics, 103, 350-376. https://doi.org/10.1016/j.jfineco.2011.09.005

Lazear, E. P., \& Rosen, S. (1981). Rank-Order Tournament as Optimum Labor Contracts. Journal of Political Economy, 89, 841-864. https://doi.org/10.1086/261010

Main, B., O’Reilly, C., \& Wade, J. (1993). Top Executive Pay: Tournament or Teamwork? Journal of Law and Economics, 11, 606-628. https://doi.org/10.1086/298309

Smith-Doerr, L., Manev, I. M., \& Rizova, P. (2004). The Meaning of Success: Network Position and the Social Construction of Project Outcomes in an R \& D Lab. Journal of Engineering and Technology, 21, 51-81.

https://doi.org/10.1016/j.jengtecman.2003.12.004 